\title{
Ecological economics to protect the planet from ecocide and free people from iron cage consumerism
}

\author{
Rouf, Kazi Abdur $\bowtie$ \\ University of Toronto and Noble International University, USA (rouf56@yahoo.ca)
}

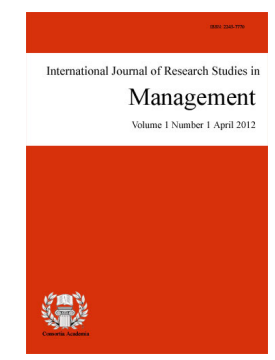

ISSN: $2243-7770$

Accepted: 31 October 2013 Online ISSN: 2243-7789

OPEN ACCESS

\section{Abstract}

This paper reviews Tim Jackson's (2011) book 'Prosperity without Growth: Economics for a Finite Planet' and justifies restless capitalistic consumption economic growth doesn't necessarily deliver genuine green altruistic social progress. Although economic growth is the foundation of social prosperity, the existing globalized liberal monopoly based on a consumer market economy, ecocides (destroy ecology) our planet. Moreover, investments turn into debt crisis by creating social inequalities, unemployment, and miserable poverty in the world. This contributes to social recession and jeopardizes civil sustainable development (Jackson, 2011). Therefore, Tim Jackson (2011) in his book mentions that a new social and ecological altruistic vision of prosperity based on a green sustainable economy is urgent and essential. The paper also finds that capitalist prosperity is not synonymous with ecocide material wealth. To address this ecocide committed by rampant capitalism, and to generate civic common prosperous green social economy for all, this paper suggests states should deregulate some macroeconomic policies and emphasis more on green social micro economics policies and strategies so the iron grip of the unethical consumerism and its immoral social logic could be dismantled. However, it is also essential the state should focus on the micro-economic community development policies and strategies handled with environmental care. As a result, this development would create altruistic human beings and establish eco-friendly environmental justice in the world.

Keywords: economic growth and prosperity; consumer capitalism; ecological debt; iron cage consumerism; Cinderella economy; ecological investment; hedonism; work sharing policy 


\section{Ecological economics to protect the planet from ecocide and free people from iron cage consumerism}

\section{Introduction}

This paper is a summary with a review of the book 'Prosperity without Growth: Economics for a Finite Planet', London, EarthScan, written by Tim Jackson (2011). This paper first provides a chapter wise summary, then second, analyses the iron cage consumerism, and in the end, highlights the rethinking of people-oriented improvement in green deal stimulus economy that can improve people-centered private and public lives, and protect ecocide of the planet Earth. The book has twelve chapters and two appendices. Appendix-1 is a culmination of the summary of workshop reports and themes of the UK Sustainable Development Commission (SDC) 2003-2011. The SDC has four themes extracted from its workshops: reports-visions of prosperity, 'economy lite', confronting structure and living well (SDC 2009a). Appendix-2 has short delineations of proposed ecological macro-economics. The book contains frightening climate change and ecocide information. It also debates the negative impacts of economic growth vs. the positive green economic prosperity.

\section{The Chapters}

\subsection{Money making Capitalism vs. Human prosperity}

This paper first briefly discusses all chapters. Chapter one looks at difference between existing capitalist economic growth and prosperity where the author points out those different patterns of economic growth affect human prosperity and try to eliminate hunger, homelessness, poverty, and injustice, and hopes for a secure and peaceful world. The author states that positive development is a common concern - people need to make a better society for their children and a fairer world. Prosperity is a shared vision. Monolithic profit-oriented economic growth is a danger of losing prosperity of a shared and lasting prosperity. Prosperity isn't obviously synonymous with income or wealth. The existence of ecological limits to human activity may be one of these. The concept of economic prosperity with economic growth is a modern concept. Although nowadays global economy is 68 times bigger than it was in 1800 in Malthus days (Jackson, p. 6), growth has delivered inequality. Capitalist societal principle of accumulation of wealth has resulted in resource scarcity and climate change. However, capitalism does not question rapid deforestation, historically unprecedented biodiversity loss, the collapse of fish stocks, water scarcity, air pollution, and the pollution of soil and water supplies. Hence, Jackson (2011) in this context suggests for the necessity to reconcile our aspirations for good life with constraints of a finite planet and find means for human society to flourish in the context of ecological limits (Ibid, p. 2). Climate change and oil peak are a concern for ecological destruction and even fear of economic collapse. We should meet the needs of our planet and support our future population. The author suggests that green stimulus economic plan should be created by green economists. It is urgent because our planet population could reach nine billion within few decades. However, the concept of governance needs a renewal. We should not focus only on our national Gross National Product (GDP).

Chapter Two, 'The Age of Irresponsibility', highlights different villains of economic frauds in the UK, and the US-those who made the banking crisis of 2008, led the world to the edge of financial disaster and the world credit crisis. Those villains hide the facts from the balance sheets. In mid-2008, advanced economics were facing the prospect of 'stagflation'. Oil process doubled in July 2008, while food prices rose by 66 per cent, sparking civil unrest in some poorer nations (Jackson, 2011, p. 19). Fuel crisis played a part in rising food prices that has impacted the environmental degradation. Rising carbon emissions, declining biodiversity, rampant deforestation, collapsing fish stocks, declining water supplies and degraded soils are just few of the disturbing facts. 
Ecological economics to protect the planet from ecocide and free people from iron cage consumerism

Jackson asks questions why loans were offered to people who couldn't afford them; why governments had consistently turned a blind eye or actively encouraged this 'age of irresponsibility' (Jackson, 2011, p. 18). By the end of October 2008, governments across the world had piled up a staggering \$7 trillion debt of public money more than the GDP of any country in the world except the US - to secure risky assets, underwrite threatened savings and recapitalize failing banks (Ibid, p.19). Collapse of the financial markets would have led to massive and completely unpredictable global recession. Entire nations would have been bankrupted. Commerce would have failed 'en masse'.

In 2009 the US recovery package has aimed to 'kick start' consumers' spending, protect jobs, and stimulate economic growth again. Many of the solution responses were seen as short-term interventions, designed to facilitate the restoration of business as usual. The ultimate goal was to continue growth at all cost fuelled by a massive expansion of credit and increasing levels of debt which Jackson called 'labyrinth (web) of debt'- the capitalist economy runs on debt and put people in debt. The excessive real state housing debt blocked the share markets that affected the US banking sectors and ultimately fell into financial crisis. Soros (2008) called debt financial markets 'super-bubble' on the global financial markets. The US-Federal Reserve de-regulated the financial markets and promoted the securitization of debts through complex financial derivatives.

In the third chapter, 'Prosperity as Opulence (wealth, affluence)', Jackson describes the Amarty Sen's (1999) theory of prosperity as opulence because capitalism prosperity is about material satisfaction. Opulence refers to the ready availability and steady throughput of material commodities. Material commodities are to meet the necessities of life. However, opulence is not the same as satisfaction. According to Amarty Sen, the uses of material commodities are social or psychological in nature rather than purely material. Now psychological satisfaction is buying iPhone, travelling abroad, buying a birthday present for a lover; however, GDP sums up all these market exchanges. GDP measures the total spending by households, government and investment across the nation. Spending is taken as proxy for utility. But there are huge critiques on the measure of development through GDP-failure to account for non-market services (like household or voluntary labour) or negative utilities (externalities) like pollution. Real income per head has tripled in the US since 1950. In the UK the percentage of very happy declined from 52 per cent in 1957 to 36 per cent today even through real incomes have more than doubled.

\subsection{Hungry Consumer Economy ends upon Unemployment}

Jackson treats the consumer economy as immoral. According to him, it gets endless freedom to accumulate goods, and achieves social recognition at the expense of child labour in the supply chain. Moreover, people find meaningful work at the expense of the collapse in biodiversity and participate in community life at the expense of future generations. Hence, Martha Nussbaum (2006) has gone further to explain human capabilities that include the following: life, bodily health; bodily integrity; practical reason (being able to form a good life); affiliation (being able to live with and toward others) and play, and control over one's environment.

Chapter four, 'Dilemma of Growth', speaks about modern economic theory. It means that continued economic growth is a necessary condition for a lasting prosperity. Material opulence is a condition of flourishing. Without growth, human ability to flourish diminishes substantially. Hence, Jackson (2011) raises a question: Are we, human beings, and naturally-born shoppers? Capitalist economic growth examines three related propositions: (1) Opulence, though not synonymous with prosperity, is a necessary condition for flourishing. (2) Economic growth is closely correlated with certain basic entitlements, health or education for example, that are essential to prosperity. (3) Growth is essential for maintaining economic and social stability. Even though continued growth looks ecologically unsustainable, it appears essential for lasting prosperity.

Consumer goods provide a symbolic language in which we communicate continually with each other, but what really matters to us is: family, friendship, sense of belonging, community, identity, social status, meaning and purpose in life (Jackson, 2011, p. 51). On the other hand, consumerism values are spreading all over the 
world and creating a consumer-based society. However, capitalist economic growth forgets that if the basic human entitlements such as life expectancy, health, and educational participation, rely inherently on rising income, it would cast a serious doubt on our ability to flourish growth. Different examples show that growth doesn't guarantee improved prosperity.

Unemployment rises further and the economy begins to fall into a spiral recession. Social costs rise with higher unemployment. At the same time, tax revenues decline as incomes fall and fewer goods are sold. Fiscal cutting social spending affects people's capabilities for flourishing and it is a direct hit on prosperity. Modern economics are driven towards economic growth. When consumption growth falters, people's jobs and livelihoods suffer.

\subsection{Modern Economy encourages Consumer Social Logic}

Jackson remarks that the capitalist model has no easy route to a steady state position. Its natural dynamics push it towards one of two states: expansion or collapse, because economic growth has two propositions:

$>$ Growth is unsustainable because resource consumption and rising environmental costs are compounding profound disparities in social wellbeing.

$>$ De-growth is unstable because declining consumer demand leads to rising unemployment, falling competitiveness and a spiral of recession.

'The Myth of Decoupling' is the title of the fifth chapter in which Jackson narrated the absolute decoupling and the relative decoupling. He suggests decoupling of materialistic throughput for the sake of environmental justice for our planet. Relative decoupling refers to a decline in the ecological intensity per unit of economic output, and it is about doing more with less: more economic activity with less environmental damage; more goods and services with fewer resource inputs and fewer emissions. Decoupling is about doing things more efficiently. The decline of resource impacts is called 'absolute decoupling'. This situation is essential if economic activity remains within ecological limits. Decoupling should necessarily achieve ecological targets. Absolute decoupling is essential to reduction in throughput.

Chapter six, 'The Iron Cage of Consumerism', describes the invisibility and exploitation of the consumer capitalism. Here the author finds that the modern economies have two interrelated features of economic life for growth economy: (1) Profit motive stimulates newer, better or cheaper products and services through a continual process of innovation and creative destruction. (2) Expanding consumer demand for goods driven by a complex social logic creates a throw-away society. These two factors drive 'the engine of growth' and lock us in an 'iron cage of consumerism'. Because consumer capitalism, employs labour (people) and capital (building and machinery) to produce the goods and services that people want and need. People offer up their labor and capital (savings) to firms in exchange for income. Revenue from the sale of goods and services allows firms to provide people with this income. People spend some of it on more consumer goods but they also save some. These savings are invested back to firms. This is the 'circular flow' of the economy. The public sector (government), the foreign sector, (overseas firms, households and governments) and the financial sector that mediates the financial flow of the circular money are missing here (Jackson, 2011, p. 91). All of these create a new set of possibilities: different ways of spending and producing, saving and investing. However, Baumol and Schramm (2007) mention that 'good capitalism' is wellbeing entrepreneurial capitalism which is absent in western consumer economics.

Cost minimization becomes a core task for consumer capitalism. To achieve cost reduction two other factors are involved: labour and materials. For a company, higher labour productivity lowers the cost of its products and services. Another component of capitalism is that new technologies and products continually emerge and overthrow existing technologies and products. Companies produce new products and adopt these new products to the markets with cheaper price, which is vital for them. However, the role of entrepreneurs as social visionaries is critical. The system is to sell more goods, to innovate continually, to go forward by the pursuit of 
Ecological economics to protect the planet from ecocide and free people from iron cage consumerism

growth. It is self-perpetuating system. Novelty (innovation) has become a conscript to the driver for economic expansion. Jackson (2011) says "it is the social logic that has made novelty products to appeal to consumers" (p. 97).

According to Jackson this consumer social logic means that material artifacts (products) constitute a powerful 'language of goods' we use to communicate with each other. It is not just about status, but also about identity and social affiliation (Jackson, 2011, p. 98). This social logic is everywhere in our relationships, in our homes, cars, bicycles, favourite clothes, CD or DVD collection, photographs, and so on. They allow us to identify what is sacred in our lives and distinguish it from the mundane. This kind of materialism is flawed. This restless consumption doesn't necessarily deliver genuine social progress but rather contributes to social recession. However, it is difficult to come out from this trap. Hence, Jackson says 'Consumer society locks us firmly into the iron cage of consumerism' (Ibid, p. 102). He urges for a change that would free us from this iron cage of consumerism. Freed consumerism would give us prosperity with potential to flourish, within ecological and social limits.

\subsection{Keynesianism and Green Stimulus Economy}

Chapter seven entitled "Keynesianism and the "Green New Deal" states that Keynesian economists think how to stimulate consumption growth, restore consumer confidence and stimulate high-street spending. Green economists do not agree with modern economists. Jackson thinks about a low-carbon society, which also requires investments, but it would be a program of a 'green stimulus' which has the potential to secure jobs and economic recovery in the short term. The green stimulus would provide us with energy security and technological innovation and would ensure a sustainable future for our children in the long term. Green stimulus package is a condition for continuing consumption growth. Here Jackson`s Green stimulus kick-start growth propositions have four main runners: (1) The economy will recover by itself. (2) Stimulate demand through monetary expansion. (3) Put more money in people's pockets by cutting taxes. (4) A massive investment in public sector works. Stimulating credit increases the availability of investment capital to firms. However, Jackson does not mention what kind of investment strategies are needed for people-centered credits.

The University of Massachusetts Political Economy Research Institute identified six priority areas for green investment: (1) retrofit buildings, (2) mass transit/freight rail, (3) smart grid, (4) wind power, (5) solar power and (6) next generation bio-fuels. Giant monoculture agriculture farming defeated small farmers. Hence, small farmers have shifted from agriculture to cities and started doing industry jobs. These migrating people think they could have better life for them and for their children, but they are suffering from poverty lifestyle. Therefore, Tim Jackson asserts for a 'green new deal' i.e. for green economics. Green economists support the idea of a 'green stimulus' that targets public sector investment carefully towards energy security, low-carbon infrastructures and ecological protection and has the following benefits:

$>\quad$ Freeing up resources for household spending and productive investment by reducing energy and material costs;

Deducing reliance on imports and exposure to the fragile geo-politics of energy supply;

Providing a boost to jobs in the expanding 'environmental industries' sector;

$>$ Making progress towards carbon emission reduction and

$>\quad$ Protecting valuable ecological assets and improving the quality of our future generations

Although Keynesian fiscal stimulus public funding policy is about growth through a 'multiplier' socio-economic effect, it practices capitalist for-profit oriented and immoral unsustainable economic growth. Hence, Jackson argues that returning the economy through stimulus packages are the default assumption of Keynesianism. He suggests that green bonds public security could be one option for flourishing green human capabilities.

In chapter eight, Jackson promotes the 'Ecological Macro-economics' because modern capitalism is unable to progress without iron cage consumerism. Jackson finds there is urgent need for a different kind of ecological 
macro-economics. Capabilities that flourish within ecological limits become the guiding principle for his proposed economics. Herman Daly (2008) made a cogent (strong logic) case for a 'steady state economy'- a constant stock of physical capital that lies within the regenerative and assimilative capacities of the ecosystem. However, Daly's missing point is the ability to establish economic stability under ecologically illiterate situation. Currently there is no model for common balanced macro-economic 'aggregates' among production, consumption, investment, trade, capital stock, public spending, labour, money supply and so on.

The principle macro-economic variable is the GDP. GDP is a measure of the 'busy-ness' of the economy. However, modern GDP measurement excluded externalities of economic growth- climate change, greenhouse gas effects, and environmental degradation by the industrial economy. Hence, Robert Ayres (2008) argues that a new growth engine is needed, based on non-polluting energy sources and not pollution products'. This new economic concept is the 'production and sale of de-materialized 'service', rather than material production'. Recycling, re-using, leasing, may be productive economy (Jackson, p. 129). But here the question is: Can people make enough money from these green economic activities?

We know human flourishing economy contains local community-based social enterprises such as community energy projects, local farmers' markets, food cooperatives, sports clubs, libraries, community health, and fitness centers, local repair and maintenance services, craft workshops, writing centers, community music and drama, local training and skills. However, this Cinderella economy is not a priority in the modern economics. Because the 'Cinderella economy' is the care economy that has been neglected at the margins of consumer society (Jackson, 2011, p, 131).

The concept of sharing the work has developed by a Canadian ecological economist, Peter Victor. Victor's model follows the principles of macro-economic variables: consumption, public spending, investments, productivity growth, savings rates and so on, but he keeps an account of unemployment, greenhouse gas emissions and poverty (in Jackson p. 134). His key policy intervention, used to prevent wide-scale unemployment, is a reduction in working hours. Unemployment is averted here by sharing the available work more equally across the workforce.

\subsection{Ecological Investment}

Jackson`s investment focus on resource productivity, renewable energy, clean technology, green business, climate adaptation and ecosystem enhancement. Hence, he suggests three types of green investment:

$>$ Investments that enhance resource efficiency and lead to resource cost savings ( energy efficacy, waste reduction and recycling);

$>$ Investments that care about clean or low-carbon technologies( renewable);

$>$ Investments in ecosystem enhancement (climate adaptation, a forestation, wetland renewal and so on).

The advantage of Jackson`s new ecological economics is that it abandons the mindless infatuation with labor productivity and high employment in low-carbon sectors. However, his proposed new ecological economics still contains the fundamental macroeconomics variables, which is still a concern. People will still spend money and save money.

\subsection{Alternative Sustainable Development Approach for Equitable Development}

The ninth chapter talks again about flourishing capabilities within limits. According to Tim Jackson, 'addressing the social logic of consumerism is also vital' (p. 144). It is because prosperity has to do with human ability to flourish: physically, psychologically and socially. Society falls into the grip of 'social recessions' through rising rates of anxiety and clinical depression, and increased alcoholism. As a result, community solidarity has broken down and there is a loss of trust across society (Jackson, p. 144). Jonathan Rutherford (2008) remarks that economic growth has increased commoditization and has raised social inequalities that engendered people. Amarty Sen`s (1999) arguments 'Higher incomes have been partly responsible for 
Ecological economics to protect the planet from ecocide and free people from iron cage consumerism

diminished flourishing. This is social trap (in Jackson, p. 147). Jackson remarks that the mechanism for economic growth in the consumer society is inherently flawed.

Jackson uses the term 'hedonism', which means that sources of satisfaction and sustainable life lies outside the conventional market economy (Jackson, 2011 p. 148). His 'hedonism' is synonymous to Mahtma Ghandi's 'live simple'. Such kind of spiritual desire exists in the northern Schottische Findhorn Community Traditions. Its character is like eco-village built on the principles of justice and respect for nature (Ibid, p. 150).

Presently private transport is incentivised over public transport; motorists are prioritized over pedestrians; energy supply is subsidized and protected, while demand management is often chaotic and expensive; waste disposal is cheap, economically and behaviourally; recycling demands time and effort: bring centres are few and far, and often overflowing with waste. Children are brought up as a 'shopping generation, hooked on brand, celebrity and status' (Jackson, 2011, p. 152). Moreover, the financial institutions, the media and the education systems all are damaging regulatory frameworks of the consumer capitalism. In this situation Jackson urges for several actions to flow: urging people to act on $\mathrm{CO}^{2}$; insulate their homes; turn down their thermostat; put on a jumper; drive a little less; walk a little more; spend holiday at home; buy locally produced goods. They will either go unheard or be rejected as manipulation for as long as the messages about high-street consumption point to the opposite direction (Jackson, 2011, p. 153). However, changing the social logic of consumption cannot simply be regulated to the realm of individual choice.

Tim Jackson has studied different countries in terms of income inequality and index of health and social problems, and found that life expectancy, child well-being, literacy, social mobility and trust - all are better in more equal societies. Infant mortality, obesity, teenage pregnancy, homicide rates and incidence of mental illness are all worse in less equal ones. He finds more materialistic societies are suffering from unhappiness than less materialistic societies. Even though it is challenging to make altruistic society, the materialistic vision of prosperity has to be dismantled.

Chapter ten, 'Governance for Prosperity' speaks about the role of government in the new green deal economics. Here Jackson identifies two specific components of ecological economics. (1) Fix the economics to develop a new ecologically literate macro-economic. (2) Change the social logic of consumerism. These alternatives go beyond making basic systems of provision (of food, housing, transport) more sustainable. This unproductive social logic status competition increases material throughput and creates distress in society. However, the question is how a shared prosperity can be achieved in a pluralistic society. According to him, the state has to play a crucial role in making the society safer. So making progress will depend on engaging a wider community into public policy debate. It is legitimate for the state to intervene in changing the social logic of consumerism. Growth calls us to be myopic (narrow minded) and individualistic novelty seekers. As there is a tension between selfishness and altruism Schwartz (2006), state needs to balance individual freedom against common good.

The capitalism drift has not been uniform across all nations. Different forms of capitalism exist across the word. For example, inequality to be higher in liberalized market economics than in coordinated market economics (Jackson, 2011, p. 164). In the liberalized market economics savings rates have fallen drastically in recent years and consumers' debt has soared. Unemployment rates trends are increasing in the UK, the USA, Germany, Canada and other economic growth based societies. On the other hand, unemployment was low in Denmark. People in the liberalized market economics tend to have higher per capita carbon emissions, higher infant mortality, higher teenage pregnancies and a greater percentage of people reporting that they 'feel like an outsider' (Ibid, p. 165).

A key element in the political economy of all capitalist nations requires a step in the role of government in protecting and stimulating economic growth; however, states have conflicted their role to act on social abnormalities. Rather, they promote private sector growth and materialistic individualism and encouraged the pursuit of consumer novelty. This trend has been perpetuated and undermines the legitimate role of government. 
Political change comes from leadership and popular mobilization. Authoritarianism is damaging human well-being in its own right (in Jackson, p. 168). The role of government is to provide the capabilities for its citizens to flourish within ecological limits. The conflicted state is itself a causality of growth.

Chapter eleven, 'The Transition to a Sustainable Economy', looks at possibilities for tackling climate change and delivering a lasting prosperity. Another world in possible if we collectively want it. Jackson mentions there are two possibilities: (1) revolution and (2) engagement in the painstaking work of social transformation. However, dismantling the system does not look easy either. The process would start by opening out a public and policy dialogue on the issues. Here Jackson (2011) provides three specific recommendations: (1) establishing the limits; (2) fixing the economic model and (3) changing the social logic. Not all of them can be achieved immediately, but together they can make some policy foundations from which to initiate meaningful and lasting change.

In establishing the ecological limits, it calls for (1) identifying the reduction targets for resource and emission caps which are vital for a sustainable economy. Here he uses two terms: contraction (tightening, reducing) and convergence (union, meeting), in which equal per capita allowances could establish under an ecological cap that converges towards a sustainable level. This approach can be applied to carbon. Similar caps should be established for the extraction of scarce non-renewable resources, for the emissions of wastes (particularly toxic and hazardous wastes), and for the drawing down of 'fossil' groundwater supplies. (2) Fiscal reform of new taxes on resource use or carbon would be offset through reductions in taxes for sustainability and (3) green sustainability is the support for ecological transition in developing countries. Investment in renewable energy, energy efficiency, resource efficiency, low carbon infrastructures and the protection of carbon sinks (forests) and biodiversity will remain vital. He emphasises that a carbon levy should be paid by richer nations on imports from developing countries or Tobin tax on international currency transfers.

In addition to these measures, used for fixing the economic model, it requires a change in the development of a new ecological macro-economics: (1) Developing an ecological macro-economic with strict emissions and resource use limits. (2) Investing in mass jobs, assets and infrastructures. (3) Increasing financial and fiscal prudence. (4) Revising the national accounts. Jackson's ecological investments include: (a) retrofitting buildings with energy and carbon-saving measures; (b) using renewable energy technologies; (c) redesigning utility networks, in particular the electricity grid; (d) developing public transport infrastructures; (e) creating public spaces, green spaces and libraries, and so on; and (f) providing ecosystem maintenance and protection. His financial and fiscal prudence are reforming the regulation of national and international financial markets, reducing excessive executive remuneration packages and providing greater protection against consumer debt and greater incentives for domestic saving. In order to execute and to stabilize financial markets, governments should retain full control over the money supply. GDP measures the amount of spending and saving by consumers, but it only measures economic activities that capture the external cost of pollution, and long-term environmental damage etc. Therefore it is essential to revise the national accounts.

Apart from these economic measures, Tim Jackson suggests changing the social logic. Social logic that locks people into materialistic consumption is extremely powerful, but detrimental to ecological and psychological factors. For long lasting prosperity people would need to break free from this damaging dynamic. Here Tim Jackson (2011) mentions five tasks for sustainable and fulfilling lives: (1) developing working time policy; (2) tackling systematic inequality; (3) measuring capabilities and flourishing; (4) strengthening social capital; and (5) dismantling the culture of consumerism.

We should reduce working hours and distribute residual hours to other unemployed people. Tackling inequality would reduce social costs, improve quality of life and change the dynamic of status consumption. These can be done through revised income-tax structures, minimum and maximum income levels, and improved access to good quality education, anti-discrimination legislation, anti-crime measures and improving the local environment in deprived areas. Systematic assessment of people's capabilities for flourishing across the nation 
would be in place. Assessments of 'outcome variables' are healthy life expectancy, educational participation, trust, community resilience and participation in the life of society. Moreover, in order to strengthen the social capital, it is necessary to create resilient social communities to absorb the face of economic shocks. Policies would include: creating and protecting shared public spaces; encouraging community-based sustainability initiatives; reducing geographical labour mobility; providing training for green jobs; offering better access to lifelong learning and skills; placing more responsibility for planning in the hands of local communities, and protecting public service broadcasting, museum funding, public libraries, parks and green spaces; promoting third sector.

In order to dismantle the culture of consumerism, another important task to do is to destroy the complex social logic incentive structures that the capitalist has constructed. Discourage throw-away society. Communities should have the right to reserve spaces free of commercialism, where citizens can congregate or exchange their ideas on an 'equal footing' (Jackson, 2011). The 'fair trade' could protect ecological and ethical standards along all supply chains. New trading standards need to be placed to address the durability of consumer products. However, the proposals outlined by Jackson need political will and this process must start by developing financial and ecological prudence at home. Jackson says: 'Prosperity without growth is not a utopian dream but a new type of financial plan and ecological planning and policies that are necessary for prosperity' (Ibid, 2011, p. $185)$.

The final chapter, 'A Lasting Prosperity', notes that economic activity should be taking carbon out of the atmosphere not adding to it. Technology will save us. Capitalist structures and institutions shape and are shaped by consumer logic norms and visions. Unlimited access to material goods stand in for our hopes of freedom. Big Daddy (1955) says that 'the human animal is a beast that dies and if he's got money he buys and buys and buys' (In Jackson, p. 190). Material possessions offer novelty. We are in two crises: (1) Unemployment is itself a lifestyle threat. (2) Beyond that immediate threat lays the prospect of ecological crisis. Our consumerist culture and its linguistic roots don't lie in sacrifice and hardship at all. Climate change and resource scarcity may look like tomorrow's problems. Rainforests may be 'a long way from here'.

Extreme poverty may seem like someone else's problem. Therefore, this is where transformation is needed. Policy interventions that might kick-start that process. Here Jackson recommends for individual or community-based action, which could offer 'a vital avenue for change to revitalize the notion of public goods. Green space, parks, recreation centres, sports facilities, libraries, museums, public transportation, local markets, and festivals': these are some of the building blocks for a new vision of social participation. However, there are still challenges: partly economic and partly social.

In this chapter Tim Jackson recognises community-based ecological enterprises engaged in delivering local services: food, health, public transport, community education, maintenance and repair, and recreation. These activities contribute to flourishing local living economics that are embedded in community and have the potential to provide meaningful work with a low-carbon footprint (Jackson, p. 196). Jackson in his green economics is providing human capabilities for flourishing (including decent work (Ibid, p. 193). Here material uses diminish. People are recycling. The manufacturing, construction, food-based agriculture and more conventional services such as retail, communication and financial intermediations are still important. He is not against private investments for production, but ecological investment should be geared towards ecological transformation, increased energy and resource efficiency, renewable and low-carbon technologies and infrastructures, climate adaptation and ecological enhancement. His new ecological economics has three distinct features: (1) the imposition of ecological growth; (2) the promotion of service activities', and (3) the discouragement of a throw-away society.

\subsection{Ecological Economics}

The important factor of the ecological economy is labour. Reducing overall working hours would reduce the 
economic output. It would improve the work-life balance. The strategy would be sharing out the available work through appropriate working time and employment policies. Jackson suggests for three macro-economic interventions to achieve ecological and economic stability in the new economy: (1) structural transition to service-based activities; (2) investment in ecological assets; and (3) working time policy as a stabilizing mechanism. According to him, this new economy is going to be 'less capitalistic'. The new investment economic policy is likely to change the balance between private and public investment. However, the role of the state in protecting these assets is vital.

\subsection{Hyper-individualism and Consumerism}

Hyper-individualism is over concern in consumer capitalism because a balance has been lost in our lives, in our institutions and in our economy. Here come needs to redress the balance between the self and society that would re-establish the importance of public goods for the benefit of all. The demand of the new economy calls on us to revisit and reframe the concepts of productivity, profitability, asset ownership, and control over the distribution of surplus. This new ecological economics will neither reinforce novelty, nor reinforce the social logic of consumerism. This is necessary because by the end of the century, our children and grandchildren will face a hostile climate, depleted resources, the destruction of habitats, and the decimation of species, food scarcities, and mass migrations and almost inevitably war. So our real choice is to work for change. To transform the structure and institutions that shapes the social world to articulate a long lasting prosperity vision. At the end of the book Jackson concludes that a faulty economics is driven by a distorted social logic. However, we can have a better and fairer social logic by believing in human flourishing capacity and community well-being within our ecological limits (Jackson, p. 204). In order to make these ideas into tasks, we need grass-roots activism and community engagement. He asks for three specific dimensions of tasks: (1) establish ecological bounds on human activity; (2) fix the illiterate economics of relentless growth; and (3) transform the damaging social logic of consumerism into green deal economy (Ibid. 204).

\section{Conclusion}

UK Professor Tim Jackson's (2011) green ecological ideas, propositions, strategies and proposed tasks are symmetrical to green social economic epistemology. For instance, similar notions of examples can be found in Canadian Professor Jack Quarter's (2000) thoughts, where he proposes the multipurpose cooperatives in which marginalised people would organize themselves and work cooperatively in enterprising, transporting, constructing housing, cooking, baking, laundering, farming and food sharing, and where members of the cooperatives could have democratic ownerships of their financing businesses and workplace. Rouf (2012) advocates for promoting the neighbourhood mini cooperatives (NMCs) where NMCs members could engage in social enterprises such as shared kitchens, laundry facilities, satellite fresh food businesses, coaching centres, vegetable gardening, day care and other facilities, where neighbours could work collectively.

These common facilities could help particularly women by freeing them from extreme double burden jobs in community public space and private space. Such kind of neighbourhood mini cooperatives can support low income employees' public and private life, their affordability, reduce their isolation, and support child care. This neighbourhood mini cooperative strategy and Cinderella households' economy would consume less non-renewable energy and support public and private life by providing shared kitchens, laundries, day care centres, shared public transport and a common place for working together.

The ecocide destruction is the devastating consequence of excavation for crude oil at the Canadian tar sands. But this is only one example of ecocide. Each day 150 living species become extinct, 1,000 acres of peat bogs are excavated and 150,000 acres of tropical rainforest are destroyed. Each day, 2 million tons of toxic waste is dumped in to our rivers and seas, 22 million tons of oil are extracted and 100 million tons of greenhouse gases are released (Ecocide, 2012). Our land is being destroyed, the water we drink is being poisoned and the air breath is polluted. This situation could get worse, as climate changes are predicted to increase the spread of 
disease, conflict and extreme weather events.

The cost of destruction to the planet by the top 3,000 corporations as estimated at $\$ 2.2$ trillion in 2008 (Ecocide 2012). This figure is growing. We are falling to look to the consequences of our actions. CEOs of these companies are not held responsible or damage they are causing. The consumer free market economy is responsible for ecocide our planet. Therefore, it is urgent make accountable to the corporations those are destroy our planet.

Tim Jackson (2011) writes this book mainly by focusing on consumerism society and its effects all over the world, especially the western economies. However, there are vast changes that have taken place in the economy, technology, education, female labor force participation, and the environment in developing countries too, because of trade liberalization and globalisation. However, Tim Jackson skips these phenomena. Moreover, micro-level innovations in social, economic and environmental programs that have positive contributions to environment and society have initiated all over the world, which are not much illustrated in the book. Also, the real state industrial strategy of high-rise building constructions is massively increasing in the world that has changed people`s lifestyles, which is not mentioned in the Jackson's book. Conversely, neighbourhood housing construction strategies are becoming less of a priority in housing design and construction. Simultaneously, the GNP would need to be reworked in order to properly account for women's labor at home as well as outside it. In addition to these, more approaches to social planning should involve jobs, housing, transportation and childcare. On the other hand, in the area of architecture and planning no major changes can take place until the economic and social policies have been agreed upon. These points are essential for human and environmental justice and peace too.

\subsection{Contributions}

The significant contributions of the book are not only to inform readers about social, economic and environmental destructions of capitalism, it also suggests green development processes. The book provides many statistical facts and figures that alarm us about the destruction process of the world ecology. It warns us the Planet is at risk for providing peaceful healthy equitable living for its living species. The book raises many issues like consumer social logic economy, manufacturing economy, toxic debt and distance travel goods destructive economy because these modern economics are unsustainable and harmful to ecology. The book not only critics consumer capitalism, but also proposes many alternative green development processes, policies and strategies that are rare in other books. Moreover, the book concepts and themes inform us about new green economic sustainability process. The book has many new concepts like unethical social logic, toxic debt and iron cage consumerism etc. that warns readers that capitalism drives us to unsustainable volatile danger economic growth at the expenses of environment, which is unacceptable.

The book's new concepts, themes and theories are not utopian rather they are supported by references and research findings. The book contains many realistic ideas and suggestions that have practical implications. For example, Cinderella economy has not been counted by many states for many centuries. However, Cinderella economics have huge contributions to micro economics and macroeconomics. Hence fiscal policy makers and evaluators cannot ignore the importance of the Cinderella Economics rather they could count it for the economic wellbeing of people. The thoughts of the book have many social and ecological implications too. These thoughts can be applied to address contemporary different issues like unemployment, poverty, environmental destruction, unjust volatile economic growth and iron cage consumerism. Moreover, the book is full of many unique research literatures and theories that feed to ecological economics teaching and learning. Many teachers, researchers and policy makers can use this book as a required text for their teaching. Even the author refers this book as a required reading text to his ecological economics students.

It can be concluded from the above review that immoral economic consumer capitalism creates a faulty social logic, which ecocides our planet. Therefore, green deal ecological economics would provide alternative 
Rouf, K. A.

strategies for countering the growth-based economy and flourishing human capabilities prosperity. In order to construct an ideal society in which all human beings are entitled to basic human rights economically and socially, the world needs to correctly identify the basic needs of all its citizens. Following this identification of needs, ecological economists, sociologists, politicians, planners, builders and policymakers must work together for better ecological economic plans to improve citizens' lives and to safe our planet from an ecological disaster.

\section{References:}

Ayres, R. (2008). Sustainability economics: Where do we stand? Ecological economics 67, 281-310. http://dx.doi.org/10.1016/j.ecolecon.2007.12.009

Baumol, W., Latin, R., \& Schramm, C. (2007). Good Capitalism, Bad Capitalism and the Economics of Growth and Prosperity. Newhaven and London: Yale University Press.

Booth, D. (2004). Hooked on growth-economic addictions and the environment. New York: Rowman and Littlefield.

Daly, H. (2008). A steady-state economy'. Think-piece for the SDC workshop 'Confronting Structure. April 2008. London; Sustainable Development Commission. Retrieved January 13, 2013, from www.sd-commission.org.uk/pages/redefining-prosperity.html

Ecocide. (2012). What is Ecocide? Retrieved December 15, 2012, from www.eradicatingecocide.com

Jowell, R. C., Fitzgerald R., \& Eva, G. (Eds.). (2007). Measuring attitudes cross-nationality-lessons from the European social survey. London: Sage.

Jackson, T. (2011). Prosperity without growth: Economics for a finite planet. London: EarthScan.

Kasser, T. (2007). The vision of prosperity: Think-piece for the SDC's redefining prosperity project. London: Sustainable Development Commission.

Keynes, J. M. (1930). Economic possibilities for our grandchildren-essays in persuasion. New York; W.W. Norton \& CO.

Layard, R. (2005). Happiness. London: Penguin.

OECD (2008). Growing unequal? Income inequality and poverty in OCD countries. Paris: Organization for Economic Co-operation and Development.

Putnam, R. (2001). Bowling alone: The collapse and revival of American community. New York: Simon and Schuster.

Quarter, J. (2000). Beyond the bottom line: Socially innovative business owners. Westport CT: Greenwod/Quorum.

Rouf, K. A. (2012). Group-based micro-borrowers social space development policies in Bangladesh- A case study Grameen Bank Sixteen Decisions. Potentia. Issue-4. Centre for International Policy Studies Centre. Ottawa: University of Ottawa.

Rutherford, J. (2008). Wellbeing, economic growth and recession: Think-piece for the SDC workshop-'Living Well-Within limits. March 2008. London: Sustainable Development Commission. Retrieved January 15, 2013, from www.sd-commission.org.uk/pages/redefining-prosoerity.html

Schwartz, S. (2006). Value orientations; Measurement, antecedents and consequences across nations. In Jowell, R., Roberts, C., R. Fitzgerald, R. \& Eva, G. (Eds.), Measuring Attitudes Cross-nationally-lessons from the European Social Survey (pp. 169-196). London: Sage.

SDC. (2009a). Prosperity without Growth. The transition to a sustainable economy. London: Sustainable Development Commission.

SDC. (2009b). Prosperity without Growth. The transition to a sustainable economy. London: Sustainable Development Commission.

Sen, A. (1999). Development as Freedom. Oxford: Oxford University Press.

Victor, P. (2008a). Managing without growth: Think piece for the SDC workshop-Confronting Structure, April 2008. London; Sustainable Development Commission. Retrieved January 20, 2013, from www.sd-commission-org.uk/pages/redefining-prosperity.html 